\title{
Pulya-ranyi
}

\section{Winds of Change}

\section{WANTA SteVe JAmpIJINPA PATRICK}

Milpirri is a Warlpiri way to get country to express itself. Country is expressing itself all the time. All around Australia, Indigenous people, culture and art express (in various forms) what animals, plants and the elements, including weather and the seasons themselves-look like and speak like. How they tell history stories and knowledge that becomes history. This is how culture teaches us and cultivates us, as the soil is cultivated, and as if we are its cultivators. Who is the gardener ultimately and who is the garden?

These knowledges and histories of country are in forms that have been called songlines, dances, paintings, petroglyphs, engravings and artefacts. For Warlpiri (or anyone born in this country)-you are responsible to remember who you are. And

\section{ISSN 1837-8692}

Cultural Studies Review 2015. @ 2015 Wanta Steve Jampijinpa Patrick. This is an Open Access article distributed under the terms of the Creative Commons Attribution 4.0 Unported (CC BY 4.0) License (https://creativecommons.org/licenses/by/4.0/), allowing third parties to copy and redistribute the material in any medium or format and to remix, transform, and build upon the material for any purpose, even commercially, provided the original work is properly cited and states its license. 


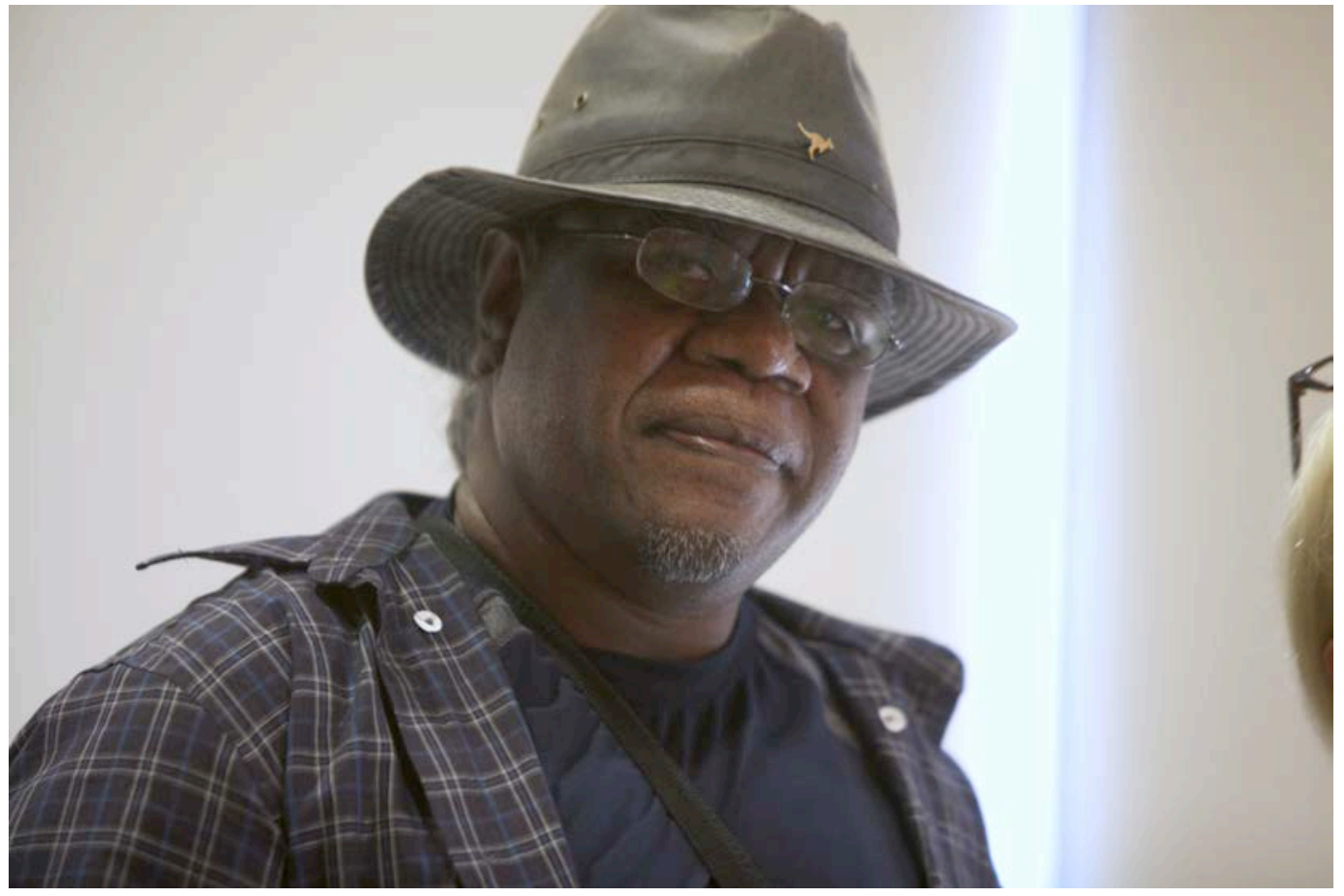

Image 1: Wanta Steve Jampijinpa Patrick delivering his Keynote talk, Same But Different 2013,

Alice Springs NT (photograph: O. Eclipse; image @ Wanta Steve Jampijinpa Patrick and Same But Different)

now, we got Kardiya (non-Warlpiri, Whitefellas) living here and we gotta to teach them how to maintain country's identity. This is what Milpirri is about. It's about not having foreign kuruwarri (mark, design, law) overshadowing our own country's kuruwarri of the Emu and Kangaroo. If we try and live under the Unicorn and the Lion (under English or British colonial kuruwarri), then we can't sit down properly with the Kangaroo and the Emu (Australia's kuruwarri). The Unicorn and the Lion are too foreign. This is not Unicorn and Lion country, it is the country of the Emu and the Kangaroo.

What if we don't know how the plants and animals and weather here in Australia speak, what if we can't listen to the Kingdom of the Emu and the Kangaroo? What if we become so ignorant we won't be able to relate to our own plants and animals and weather anymore? How can I call myself Warlpiri if I can't speak Warlpiri anymore or do Warlpiri ceremony?

This is why I started thinking about Milpirri. About how to shape understanding for both Yapa (Aboriginal people, human beings) and Kardiya (non-Aboriginal 
people) by using Milpirri as a way to get both sides thinking about what country is really trying to remind us about: our home, our country, our identity; about how to learn from Mother Earth and Father Sky. These two are our ceiling and our floor. We dwell on them and in them.

Milpirri is really a metaphor for bringing Kardiya and Yapa together. It is the hot air rising and cold air falling that makes the thunderhead or ceremony cloud so full of rage and lightning thrashing; a cumulonimbus cloud that is full of fury. The moment where these two different knowledges clash: 'how can you understand me, you are so different?' These two, the cold air and the hot air, are trying to adjust to each other, and it isn't easy. When the hot air rises, and cold air falls, it's about adjusting to one another; a disagreement then an agreement after. But after the big storm, when the hot air and cold air meet, after it settles down, that's when it gives birth to this cloud called Milpirri. Then we can recognise the ground-up duty of care, a responsibility for the country's knowledge. This is Yapa people's responsibility, and when the clouds go really smooth at the top of that ceremony thunderhead, we call that in Warlpiri mukardi (or ceremonial head-dress).

The cold air is Kardiya knowledge. The rain rejuvenates the possibilities for two different kinds of knowledge coming to an agreement. A better understanding of each other on both sides occurs; this is the rain and the relief that comes. When it rains, the nourishment of country occurs. Once the lightning settles, the rain comes, which is this country's understanding of how we should work together and how achieving this can, sometimes, be a bit rough. This is what the Milpirri clouds represent.

Milpirri is a Warlpiri version of this country's kuruwarri. Warlpiri don't own the Milpirri stories, the Milpirri stories own Warlpiri. We share this nourishment with you Kardiya in order for everyone to come and feed off what is written and what is embedded in the land. This is the best and proper food. I'll bet if you look around in this county for that Lion and the Unicorn you won't find it!

We have Milpirri every two years, since 2005, at Lajamanu. The Milpirri Festival is produced in partnership with Tracks Dance Company from Darwin [see Jennifer Biddle in conversation with Track Dance Company, this volume, for further details]. Old people, they dance and express the meaning of the story in traditional NgurraKurlu (Family, Law, Land, Language, Ceremony, see further below) and the kids do 
their own version of this same story interpreted through hip hop. We write music in conjunction with Tracks who provide digital recording for us, but it's our own compositions in Warlpiri and in English. School age kids dance in accordance with their Ngurra-Kurlu skin groups (see further below).

After Milpirri, it rains because Milpirri is that time of the year when Warlpiri hold all their ceremonies and it's the beginning of the time that country feeds us all.

Our inspiration for Milpirri comes from the way that ganma-a place where two rivers meet-is used by the Yolnu of eastern Arnhem Land as a model for their intercultural and educational interactions with other peoples and cultures. ${ }^{1}$ Yes, well out in the desert, we have rivers, but most of them are dry! So we looked to the wind story-about how hot air from the land rises, and cold air falls from above-to give us this metaphor for people coming together. The Yaalakapura 'Peregrine falcon', which also comes from this same songline, reminds us of how knowledge is to be passed on, and how we can use it our advantage. Its story teaches us that, in this life, the hunter and the hunted are both within us, and that this is how we learn. That knowledge is there to cultivate us - to cultivate us before we can cultivate the land. Yes, that is the Warlpiri way.

-NGURRA-KURLU

I came to think about Milpirri after working at Lajamanu School since 2004. A question had been ringing in my head about the lack of bilingual or two-way learning in our Australian Indigenous communities. ${ }^{2}$ For years, I have been teaching young people about our ceremonies, some of which are no longer practiced today, and it is often very hard to tell our children that their language is important, that their ceremonies are important, that their skin names are important, and that all these things stem from the law of this land.

This is what I call Ngurra-kurlu. Ngurra-kurlu is all about our place and sense of home. It consists of Family, Law, Land, Language, and Ceremony. ${ }^{3}$ Once we lose these five elements we become homeless people-people without the ability to understand our own home. We become feral in our own land. We live in our home without really knowing how to look after it, and we run the risk of desecrating our home. So we must look for a new way to teach our kids so that they understand their home through Ngurra-kurlu. 
In Lajamanu until recent decades, my culture has always been taught by our elders and through going to ceremonies, so that we understand how to read the land and how it speaks to us. So how do we express this to our children today? Our young kids nowadays are influenced by things that are really foreign to them, and the way they look at the land is not the way the older generations and our ancestors have looked at it. ${ }^{4}$ No, so trying to teach them through the two ways of what I call the foreign way and the original way is a way of trying to bring back what is supposed to be our Warlpiri way of living in our home.

Ngurra-kurlu is the five pillars of the way this land has always been, and Indigenous people have always looked at this country-how it is written in everything around us and even embedded within ourselves. Yes, every day we have to express Ngurra-kurlu. Even when we are walking and talking, we must still use our bodies to express Ngurra-kurlu to move like the wind and, with our sounds, make it talk.

The Milpirri Festival is one such way that we have recently developed to teach our children about Ngurra-kurlu. The theme of Milpirri in 2012 was Pulya-ranyi, the 'Winds of Change'. Pulya-ranyi is a wind songline that talks about the wind controlling fire, and how fire that glows will consume and become stronger. Yes, so Pulya-ranyi is about people's potential, but how to we make it move? How do we control it? How do we teach it again and pass on knowledge? This is all part of the Milpirri model-speak to the land and the land will speak back.

\section{- SKIN NAMES}

Integral to each new Milpirri is the way that all our performers are dressed in one of four colours-blue, green, red and yellow-in accordance with traditional Warlpiri kinship. As shown in the following table, these colours represent our four corresponding patrifilial groups-Wanyaparnta 'Emu', Parra 'Day', Wawirri 'Kangaroo' and Munga 'Night' - and the eight constituent subsections or skin names through which all in Warlpiri society are related. Each of these eight subsections has a masculine and feminine form, and can further be sorted equally into left and right matrimoiety groupings. ${ }^{5}$ 

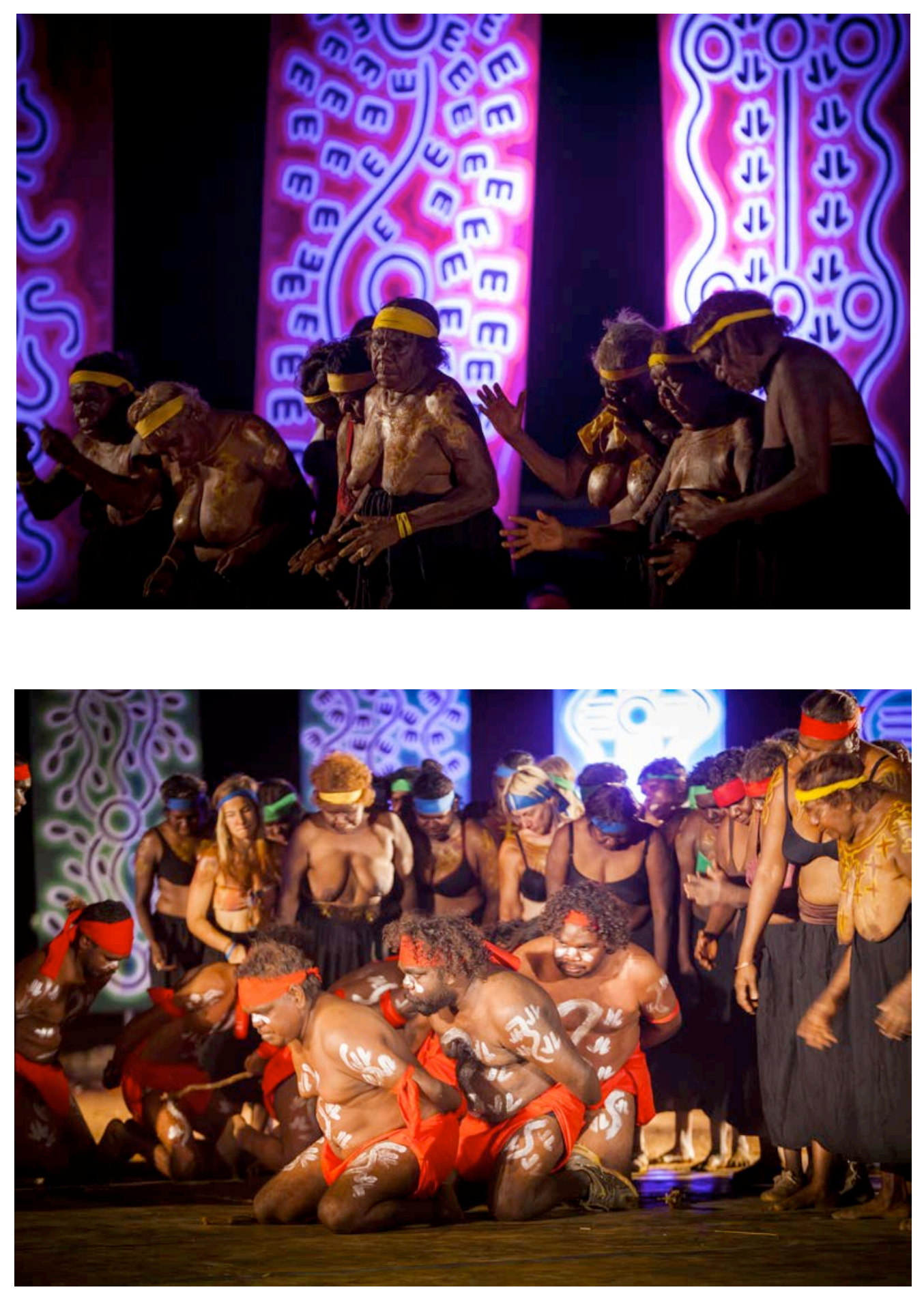

Images 2 and 3: Dancers perform at Milpirri 2012, Lajamanu NT (photographs: P. Eve; image $($ ) Tracks Dance Company 2012) 
We have gel wristbands made in these four colours for children to wear during the festival on their left or right arm, so they can easily remember their skin names, and now people wear them around all the time. Even when young men break their arms during football competitions at Lajamanu, they now ask for plaster casts in these four colours! When newcomers to Warlpiri society are integrated into this system, they can also learn about traditional kinship in this new way. This is the key to equipping people with a very personal understanding of what Ngurra-kurlu means.

Through this system, we are trying to teach everyone that all these skin names are more than just names. They are really the place from where you can see your journey in life beginning. Take the name of my people, Warlpiri, which is really a contraction of Warlpa-wiri, meaning 'big wind'. Each of our four main kinship groups also represents one of the four big winds-North, East, South and West-all coming together to give us that movement to control the fire at the centre of Pulya-ranyi. By not allowing ourselves to be Pulya-ranyi, that fire cannot move anywhere. So the Milpirri Festival has now become the fire that sends out this message to all.

The Warlpiri have two main ceremonies: Jardi-warnpa, which is held by the Blue and Red groups, and Kurdiji, which is held by the Green and Yellow groups. ${ }^{6}$ Neither of these ceremonies has run in recent years, so the Milpirri Festival always uses public sequences of song and dance from them to educate everyone about our traditional law. The Witi 'two trees' sequence from the Kurdiji ceremony, for example, teaches us about consequences-the potential for our actions to hold negative and positive consequences-and the burning of leafy Witi poles at its conclusion symbolises the movement of fire from east or west to clean out the country. We also encourage children to create their own hip hop dances based on

\begin{tabular}{lllll}
\hline Colour & \multirow{2}{*}{ Patri-group } & \multicolumn{2}{l}{ Subsections (masculine/feminine) } & \multirow{2}{*}{ Wind } \\
& & Left & Right & \\
\hline Blue & Wanyaparnta & Jangala/Nangala & Jampijinpa/Nampijinpa & North \\
Green & Parra & Japangardi/Napangardi & Japanangka/Napanangka & East \\
Red & Wawirri & Jupurrula/Nupurrula & Jakamarra/Nakamarra & South \\
Yellow & Munga & Japaljarri/Napaljarri & Jungarrayi/Nungarrayi & West \\
\hline
\end{tabular}

Table 1: Colours used to portray traditional Warlpiri kinship alignments used in the Miplirri Festival 


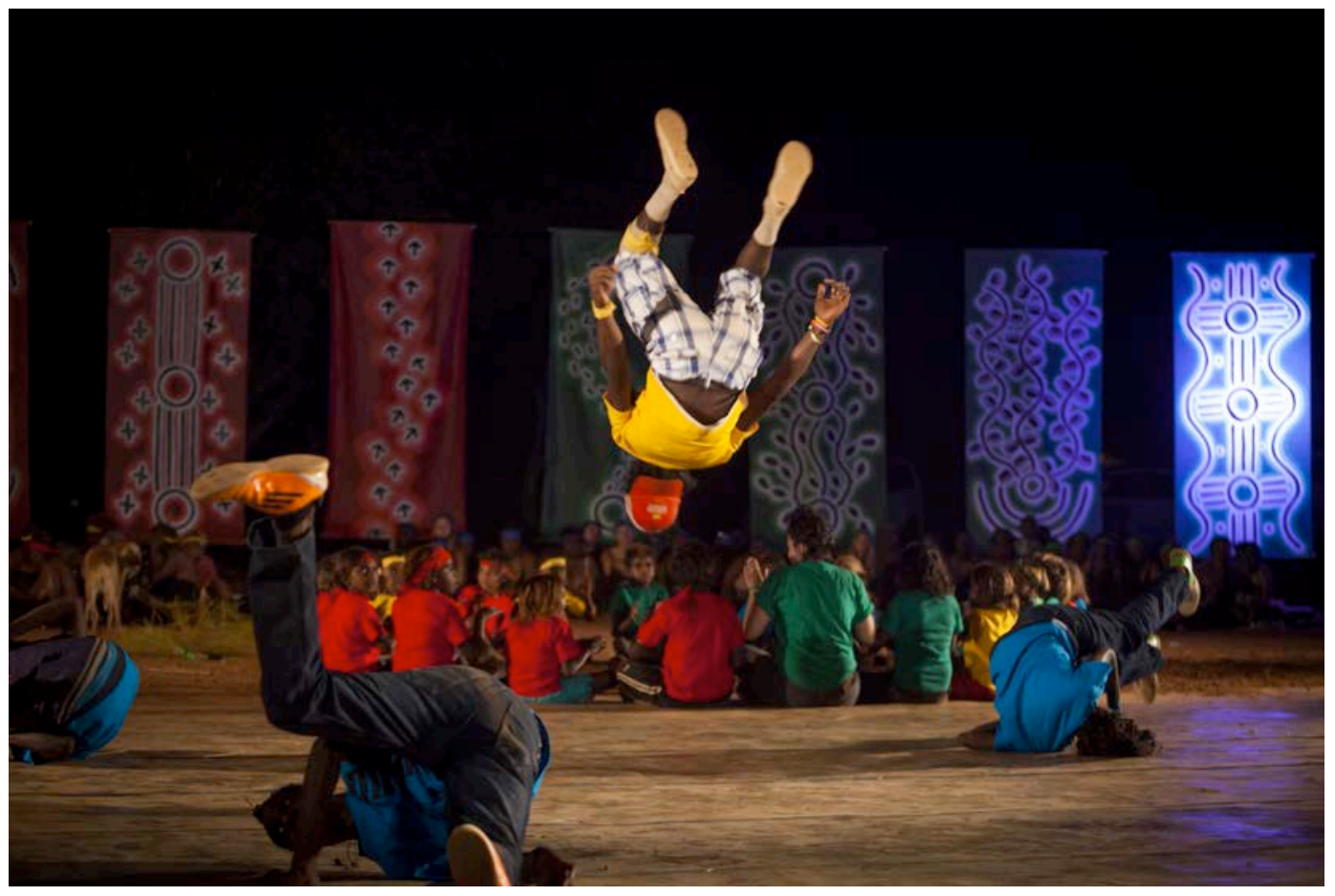

Image 4: Dancers perform at Milpirri 2012, Lajamanu NT (photograph: P. Eve; image @ Tracks Dance Company 2012)

these traditional stories. So, in the festival, you will see them performing hip hop dances that are really interpretations their own Dreamings.

So all of our skin names are more than just names. They come from the land and the sky-Mother Earth and Father Sky. All the holders of all the many different homelands that fit into our four main kinship groups-like the James family and the Patterson family - they each have their own traditional names as well, which all go back to the land and come together with the four winds to produce the Milpirri Festival.

The final song and dance sequence of each Milpirri Festival is always Warntarritarri from the Kurdiji ceremony. Its name is derived from wantarri 'gift', which relates how the sky and earth come together in the form of the Milky Way. Warntarritarri serves to remind us that each one of our lives is a gift to each other, as is everything around us, and through this understanding we can better achieve the balance of Ngurra-kurlu in our lives. 


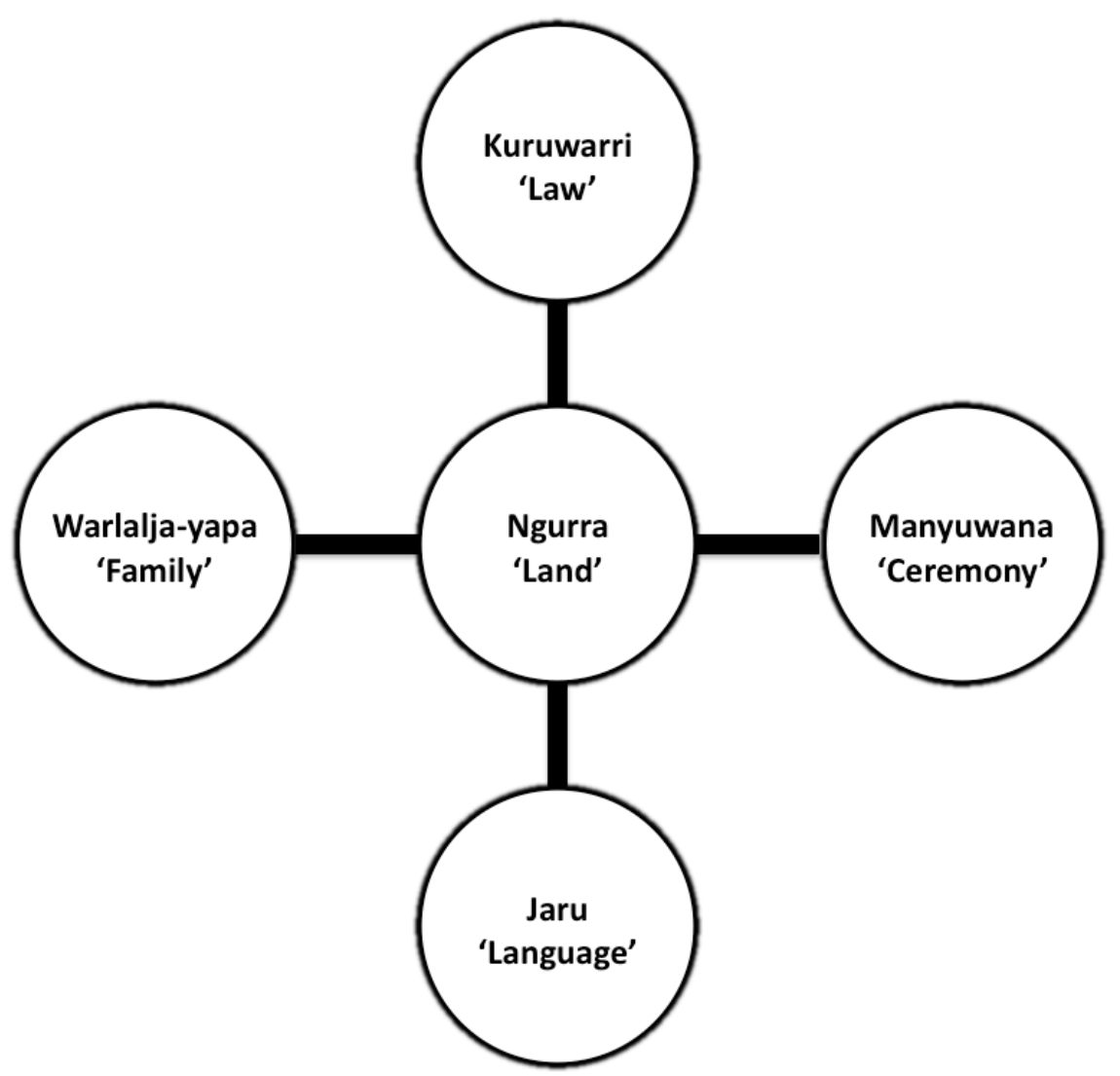

Figure 1: The Southern Cross schema for Ngurra-kurlu

This country is riddled with all these stories. They are painted in art that you now see in galleries and museums all over the world. ${ }^{7}$ But they are not things that are merely meant to look good. They are supposed to talk back to us like the land from which they come. They too express the five elements of Ngurra-kurlu-Family, Law, Land, Language, and Ceremony-as shown in the following figure with Land in the centre. This idea for Ngurra-kurlu comes from the Southern Cross constellation, which is the axis upon which the Milky Way rotates through the sky.

Now, one of the worst things we can do is to forget all of this Law-to put it aside and learn something else. This is dangerous for our identity. All this learning of the way to observe Law properly goes back to Pulya-ranyi-the words that are meant to move us and cultivate us. The sounds of the land gives us words, the words gives us songs, the songs give us ceremonies, the ceremonies give us teaching, the teaching give us our beliefs, and the beliefs gives us our identity. The most important thing to understand is how to how to learn to listen to this country. 
All of this is embedded in our country, our Law-even in the ants, the elements, and the seasons. They too all have skin names, and each a place under the Law to ensure that everything remains in place. This reminds us that we must make the effort to listen to country, to not lose our Law, but to try and bring it back to life-to bring back to existence that Ngurra-kurlu or essence of home within us.

There is no doubt that these stories if we can hear them properly, can really take us where we have never been before, and unlock some mysteries by challenging us to think about how things really work. But this is a journey for each of us to discover once the seed of learning has been planted-that little seed from the Dreaming. Let it take you and grow you up. To live in the homeland of the Kangaroo, we must understand the Emu. That I leave with you.

Wanta Steve Jampijinpa Patrick is a Warlpiri elder from Lajamanu in the Tanami Desert. He is an experienced educator and cross-media artist who has worked on numerous programs for the Northern Territory Department of Education, the North Australian Aboriginal Justice Agency and the Warlpiri Youth Development Aboriginal Corporation's acclaimed Mt Theo Program. He collaborates with Tracks Dance Company as creative director of the Milpirri Festival.

\section{-ACKNOWLEDGEMENTS}

My sincerest thanks go to the Arrernte people of Alice Springs for allowing me to speak on their country. Thanks also to Jennifer Nampijinpa Biddle for inviting me to present this keynote at the Same but Different forum; to my Milpirri Festival co-directors, Tim Jampijinpa Newth and David Japaljarri McMicken of Tracks; to the Australian Research Council for funding my Discovery Indigenous Award project, 'Early collections of Warlpiri cultural heritage and resulting community access needs in remote desert Australia'; and to my Australian National University colleagues on this project, Aaron Japangardi Corn, Stephen Japangardi Wild and Lee-Anne Napanangka Proberts.

\section{-EDITORS' NOTE}

This essay is greatly expanded from its original key note presentation. We would like to thank Jampijinpa directly for this essay, and for his ongoing support as key note speaker for Same but Different: Experimentation and Innovation in Desert Arts I (2012) and II (2013). 
-Notes

1 A. Corn and J. Gumbula, 'Rom and the Academy Repositioned: Binary Models in Yolyu Intellectual Traditions and their Application to Wider Inter-cultural Dialogues', in L. Russell (ed.), Boundary Writing: An Exploration of Race, Culture and Gender Binaries in Contemporary Australia, University of Hawai'i Press, Honolulu, 2006, pp. 170-97; A. Corn, Reflections and Voices: Exploring the Music of Yothu Yindi with Mandawuy Yunupinu, Sydney University Press, Sydney, 2009.

2 Yirrkala Community School Action Group, Towards a Ganma Curriculum in Yolyu Schools, Yirrkala School, Yirrkala, 1988; S. Harris, Two Way Aboriginal Schooling: Education and Cultural Survival, Aboriginal Studies Press, Canberra, 1990.

${ }^{3}$ S. Patrick, M. Holmes and A. Box, Ngurra-kurlu: A Way of Working with Warlpiri People, Desert Knowledge Cooperative Research Centre, Alice Springs, 2008.

${ }^{4}$ M. Hinkson, 'New Media Projects at Yuendumu: Towards a History and Analysis of Intercultural Engagement' in L. Taylor et al. (eds), The Power of Knowledge, The Resonance of Tradition, Aboriginal Studies Press, Canberra, 2005, pp. 157-68; Inge Kral and Robert G. Schwab, Learning Spaces: Youth, Literacy and New Media in Remote Indigenous Australia, ANU E Press, Canberra, 2012.

5 M.J. Meggitt, Desert People: A Study of the Walpiri Aborigines of Central Australia, Angus \& Robertson, Sydney, 1962.

${ }^{6}$ S. Wild, 'Warlpiri Music and Culture: Meaning in a Central Australian Song Series', in J. Kassler and J. Stubington (eds), Problems and Solutions: Occasional Essays in Musicology, presented to Alice M. Moyle, Hale, Sydney, 1984, pp. 86-203; S. Wild, 'Recreating the Jukurrpa: Adaptation and Innovation of Songs and Ceremonies in Warlpiri Society', in M. Clunies Ross, S. Wild and T. Donaldson (eds), Songs of Aboriginal Australia, Oceania, Sydney, 1987, pp 97-120.

7 Jennifer Biddle, 'When Not Writing is Writing', Australian Aboriginal Studies, no. 1, pp. 21-33, 1996; Jennifer Biddle, 'Writing Without Ink: Literacy, Methodology and Cultural Difference' in A Lee and C Poynton (eds), Culture and Text, Allen \& Unwin, Sydney, 2000, pp. 170-87; Jennifer Biddle, Breasts, Bodies, Canvas: Central Desert Art as Experience, UNSW Press, Sydney, 2007; F. Dussart, 'A Body Painting in Translation', in H. Morphy and M. Banks (eds), Rethinking Visual Anthropology, Yale University Press, New Haven, 1997, pp. 186-202.

\section{-BibliographY}

Biddle, J., 'When Not Writing is Writing', Australian Aboriginal Studies, no. 1, 1996.

Biddle, J., 'Writing Without Ink: Literacy, Methodology and Cultural Difference' in A. Lee and C. Poynton (eds), Culture and Text, Allen \& Unwin, Sydney, 2000.

Biddle, J., Breasts, Bodies, Canvas: Central Desert Art as Experience, UNSW Press, Sydney, 2007.

Corn, A. and J. Gumbula, 'Rom and the Academy Repositioned: Binary Models in Yolnu Intellectual Traditions and their Application to Wider Inter-cultural Dialogues', in L. Russell (ed.), 
Boundary Writing: An Exploration of Race, Culture and Gender Binaries in Contemporary Australia, University of Hawai'i Press, Honolulu, 2006.

Corn, A., Reflections and Voices: Exploring the Music of Yothu Yindi with Mandawuy Yunupinu, Sydney University Press, Sydney, 2009.

Dussart, F., 'A Body Painting in Translation', in H. Morphy and M. Banks (eds), Rethinking Visual Anthropology, Yale University Press, New Haven, 1997.

Harris, S., Two Way Aboriginal Schooling: Education and Cultural Survival, Aboriginal Studies Press, Canberra, 1990.

Hinkson, M., 'New Media Projects at Yuendumu: Towards a History and Analysis of Intercultural Engagement' in L. Taylor, G. Ward, G. Henderson, R. Davis and L.A. Wallis (eds), The Power of Knowledge, The Resonance of Tradition, Aboriginal Studies Press, Canberra, 2005.

Kral, I. and Robert G. Schwab, Learning Spaces: Youth, Literacy and New Media in Remote Indigenous Australia, ANU E Press, Canberra, 2012.

Meggitt, M.J., Desert People: A Study of the Walpiri Aborigines of Central Australia, Angus, Sydney, 1962.

Patrick, S., M. Holmes and A. Box, Ngurra-kurlu: A Way of Working with Warlpiri People, Desert Knowledge Cooperative Research Centre, Alice Springs, 2008.

Wild, S., 'Recreating the Jukurrpa: Adaptation and Innovation of Songs and Ceremonies in Warlpiri Society', in M. Clunies Ross, S. Wild and T. Donaldson (eds), Songs of Aboriginal Australia, Oceania, Sydney, 1987.

Wild, S., 'Warlpiri Music and Culture: Meaning in a Central Australian Song Series', in J. Kassler and J. Stubington (eds), Problems and Solutions: Occasional Essays in Musicology, presented to Alice M. Moyle, Hale, Sydney, 1984.

Yirrkala Community School Action Group, Towards a Ganma Curriculum in Yolyu Schools, Yirrkala School,

See also

Patrick, S. (creat. dir.) 2005 Milpirri Festival: Jardi-warnpa (Lajamanu, Tracks Dance Company).

Patrick, S. 2007 Milpirri Festival: Kurdiji (Lajamanu, Tracks Dance Company).

Patrick, S. 2009 Milpirri Festival: Juntu Purlapa (Lajamanu, Tracks Dance Company).

Patrick, S. 2011 Milpirri Festival: Kurlumpurrungu (Lajamanu, Tracks Dance Company).

Patrick, S. 2012 Milpirri Festival: Pulya-ranyi (Lajamanu, Tracks Dance Company).

Patrick, S. and A. Box 'Milpirri: Performance as a Bridge that Joins the Ancient with the Modern', Ngoonjook, no. 33, 2008, pp. 53-60. 